\title{
Napalm and After: The Politics of Grace Paley's Short Fiction

\author{
JUDIE NEWMAN
} \\ University of Nottingham
}

I object not to facts but to people sitting in trees talking senselessly, voices from who knows where.

('A Conversation with my Father') ${ }^{1}$

Grace Paley's commitment to political radicalism has never been in much doubt. Comparatively few contemporary writers have accompanied American POWs home from Hanoi, been arrested on the White House Lawn, or been dragged off in shackles to serve time in the Greenwich Village Women's House of Detention. Paley's pacifist, socialist politics are also deeply rooted in a family past where memories were still fresh of Tsarist oppression - one uncle shot dead carrying the red flag, and parents who reached America only because the Tsar had a son and amnestied all political prisoners under the age of twenty-one. At this point, Paley's father (imprisoned in Archangel) and her mother (in exile) took their chances (and all their surviving relatives) and very sensibly ran for their lives. Her grandmother recalled family arguments around the table between Paley's father (Socialist), Uncle Grisha (Communist), Aunt Luba (Zionist), and Aunt Mira (also Communist). Paley's own street-wise adolescence involved the usual teenage gang fights, between adherents of the Third and Fourth Internationals.

Until recently, critics of Paley's work have tended to focus upon gender politics, and upon the feminist form of her writing, with its communal narration, revisions of conventional genre, and restoration of women's unwritten experience. ${ }^{2}$ The publication of Fust As I Thought in I998, a collection of Paley's autobiographical pieces, has drawn attention back, however, to politics in the newspaper sense of the term. ${ }^{3}$ Reviews were, at best, mixed. For Alan Wolfe, Paley exemplified an idealistic, romantic, impractical Leftism, complacently convinced of its own righteousness, and demonstrating how the Left in America 'has happily chosen the easy path of

\footnotetext{
${ }^{1}$ Grace Paley, Enormous Changes at the Last Minute (New York: Farrar, Straus, Giroux, i974; repr. London: Virago, I979), p. I62.

${ }^{2}$ See, for example, Jacqueline Taylor, Grace Paley: Illuminating the Dark Lives (Austin: University of Texas Press, I 990); Gloria Cronin, 'Melodramas of Beset Womanhood: Resistance, Subversion and Survival in the Fiction of Grace Paley', Studies in American-fewish Literature, I I.2 ( I 992), I 40-49. A discussion of Paley's work which undertakes a political analysis in terms of conversation as both form and political model is Politics and the Muse: Studies in the Politics of Recent American Literature, ed. by Adam Sorkin (Bowling Green, OH: Bowling Green State University Popular Press, I 989).

${ }^{3}$ Grace Paley, Just As I Thought (New York: Farrar, Straus, Giroux, I998).
} 
political sentiment over the difficult business of moral reckoning'. ${ }^{4}$ In his view Paley's sentimentality had converted radicalism into 'little more than a story itself', in which America is always bad, and all the countries that challenge it, implicitly good.

Only a storyteller could write in Paley's gushing terms about the idyll of North Vietnam. 'Water spinach,' she exclaims, 'is a wonderful vegetable.' And only a fabulist could write about her fellow writer Christa Wolf and never discuss her work for the East German secret police. (p. 36)

Carol Iannone, in Commentary, was (predictably) even more scathing, accusing Paley of having been seduced by a Potemkin-style display in Vietnam, and reminding her of the North Vietnamese 're-education' camps, and the fate of Vice Admiral James Stockdale. ${ }^{5}$ In her account Paley insists that American POWs were always very well treated, quoting in support the Vietnamese proverb: 'The man in the sky is a killer, bring him down; but the man on the ground is a helpless human being' (Just As I Thought, p. 79). Even without stampeding quite as far to the right as Iannone, it does seem faintly unlikely that the North Vietnamese had evolved such a perfect form of human nature that nobody ever revenged their napalmed children by taking a pitchfork to a captured airman.

Be that as it may, Paley has none the less defended the political impetus behind her stories. Interviewed in Index on Censorship, she complained:

There's some kind of inhibition in this country about writing about people who live and think politically. But I don't feel like I'm writing about seven people in the world. Its not so pathetic a minority as they want us to think. ${ }^{6}$

While some of her readers were entirely sympathetic, she recorded hostile reactions from others: 'I get people saying, what's all this politics in here? What's interesting is that in almost any other country in the world, nobody would ever dare to think of saying, what's all this politics in here?' (p. I3). Even worse, the reading public does not always get a choice in the matter. Publishers have certainly abetted a wholesale depoliticization of Paley's writing. The last three stories of Later The Same Day were first published in Mother fones (a progressive political journal) after being rejected everywhere else. ${ }^{7}$ In addition, though some of Paley's stories are frequently anthologized, they are the less overtly political tales: 'I meet people who think the only story I ever wrote was 'Goodbye and Good Luck' ('We don't say', p. I3).

So is it possible to be a storyteller and yet remain politically and morally responsible? Or does Paley convert politics into story and, perhaps more worryingly for the literary critic, story into politics? In the space available here, one story must serve as something of a test case. In 'Faith in a Tree', Faith sits in a sycamore tree, freely discoursing upon the other mothers in

4 'The Saint', New Republic, 29 June i 998, pp. 35-39, (p. 38).

5 'A Dissent on Grace Paley', Commentary, 80 (August i 985 ), 54-58.

6 Grace Paley, 'We don't say a lot of what we think', Index on Censorship, I 9. I ( I990), I 3.

${ }^{7}$ Grace Paley, Later the Same Day (New York: Farrar, Straus, Giroux, I985). 
the park around her, descending only when drawn to earth by the sight of a handsome male. When a group of war-protesters are ejected from the park by the police, Faith does not intervene, to the fury of her son Richard who promptly chalks their slogans on the blacktop, converting his mother to political involvement. The story marks a political turning point, a major change of life-direction: 'Then I met women and men in different lines of work, whose minds were made up and directed out of that sexy playground by my children's heartfelt brains, I thought more and more about the world.'8

Paley visited Vietnam in I 969 , with six others, three of them film-makers (the film was impounded on their return), the others charged with the job of accompanying POWs home. Importantly, the first version of the story (published in New American Review in I967, before Paley visited Vietnam) leaves Faith unconverted, ending as she climbs back into her tree, when she realizes that the dashing Phillip is attracted to another woman. ${ }^{9}$ The collected version adds the sudden interruption of the protesters. The story is very much two colliding stories: an initial story which is gender-political, representing the unseen lives of women, their voices interwoven with Faith's looking after children in the local park, and a second macro-political story which introduces global politics in a fairly obvious fashion. The two are ostensibly linked by the concern for children - the protesters carry a sequence of posters, one of which portrays a napalmed child. The posters are identical to those which Paley herself remembers carrying.

Years ago - ig66 or 1967 - people in the peace movement carried a poster of a well-dressed young man holding a cigarette against the arm of a child. On the poster a question was asked: Would you burn a child? In the next poster, the man applied the burning cigarette and the answer was given: When necessary. The third poster showed a child burned and crippled by American napalm. (Just As I Thought, p. I I 5)

From one point of view, however, it may be argued that the story deteriorates as story, as a result of the Vietnam material, ceasing to be a free-floating, digressive celebration of women's language and experience, to become conventional, a story with a 'twist' at the end, a sudden point which appears completely unmotivated by what precedes it. Richard's role as childconscience (shades of Little Eva) is also ambiguous. He is after all a proponent, even in his childish way, of violent intervention. He punches his mother and argues that Faith should have slugged the cop, to allow the peace demonstration to proceed. On the other hand, if the whole point of the story is the conversion of Faith to political action as a result of the demonstration, the preceding twenty pages in which a woman sits in a tree apparently babbling nonsensically, merely delay the getting of the political message. In a sense they obscure confrontation with the facts of American violence, the

\footnotetext{
${ }^{8}$ Grace Paley, Enormous Changes at the Last Minute (London: Virago, I979), p. Ioo. Subsequent references, given in the text, are to this edition of the story.

9 'Faith: In A Tree', New American Review, I-3 ( I 967), 5 I-67.
} 
implicit criticism of the fictional father, commenting intertextually on his offspring's story in 'Conversation With My Father'. The brokenbacked form of the tale brings into sharp focus the potential mismatch between form and message. Indeed it is arguable that this is part of Paley's intention. The protesters, with their violent images, are swiftly dismissed by one witness: 'They'll only turn people against them' (p. 98). The form of their action, a noisy parade, recalls the inherent problem of finding an appropriate form for political protest, in life as in story. When people form lines, hold up banners, and advance in serried ranks, to 'march' against war, they may not look very different from their militaristic opponents lined up opposite them. The images on the flags may be different, but both groups behave like armies. The form itself carries a message of aggression, despite its surface intentions. And the short story form has to address the same problem. When a short story suddenly delivers a shocking moral in a heart-stopping twist, there is a degree of textual aggression towards the reader, impaled on its point.

So what is the connection between anti-war protest and a woman babbling in a tree? Two points are significant here: Faith's bird's-eye view, and the tree itself. The story establishes an implicit contrast between narratorial omniscience and womanly limitation, drawing attention to an illustrious narrative forefather. Like some latter-day surveyor of 'The American Scene', Faith looks down upon the park and notes its pool 'in which, when Henry James could see, he saw lilies floating' (p. 78). It is, of course, Washington Square Park. This is the park where, famously, in the novel Washington Square, Catherine Sloper chose not to meet her lover, Morris Townsend, in favour of accepting his advances in a respectably furnished parlour. James described the area in I880 as having 'a kind of established repose which is not of frequent occurrence in other quarters of the long, shrill city'. ${ }^{10}$ Grace Paley was active in the movement to preserve this park from real-estate interests, and from the plan (subsequently defeated) to drive a road through it. Unlike James, Faith enjoys a view which is less tranquil, more feral, offering an image of city-as-jungle. Over the tree tops, beyond dangerous Central Park, 'far north, the deer-eyed eland and kudu survive, grazing the open pits of the Bronx Zoo' (p. 78). Faith may not enjoy godly omniscience (she distinguishes carefully between the god who looks down from 'Holy Headquarters' (p. 77) and sees everything, and herself, 'the creation of His soft second thought' (p. 78)), but her position allows for a degree of superiority none the less. Like a Foucauldian surveillant in a panopticon, Faith enjoys a panoramic view of her fellow 'prisoners', confined to the park by childcare. Although the story can be read as a celebration of womankind, her position suggests that she has the other women in her sights as much as in her sight. She comments freely, for example, on Mrs Wilson's pretentiousness, Anna's bad

${ }^{10}$ Henry James, Washington Square (London: Penguin, I963), p. I6. 
character, Mrs Finn's dogmaticism, Lynn's self-absorption. Both Adam Meyer and Minako Baba have drawn attention to the implicit condescension of her position, literally looking down on the others from superior heights. ${ }^{11}$ As the imagery establishes, she enjoys the full empire of the gaze, in her description of the playground, expanding it from microcosm to macrocosm by her nautical metaphors, (metaphors which, with their suggestions of the image of the large woman as a ship in full sail, are not necessarily complimentary). Mrs Lewis, like a large liner manouevring slowly into position, 'swings within the seconds of her latitude' (p. 78); Mrs Finn becomes a 'broad barge', with 'cabooses dragged by clothesline at her stern', with one child, her 'roaring captain', clinging to her ample 'upper deck', as she goes puffing towards the 'sandy harbor' of the playground (pp. 78-79). Sexy Lynn Ballard, tilting like a delicate sailboat, a toy for boys, floats along the same channel to 'drop light anchor' on a bench (p. 79). The suggestion is of aerial reconnaissance, a view from a crow's nest or look-out post. Faith's irony may preserve the story from sentimentality (a charge to which any writer who celebrates the experiences of mothers and children will always be exposed), but distance is also potentially a form of attack. In the story Paley plays with notions of distance in order to collapse them, to bring the potentially aggressive 'man in the sky' (even a woman merely half-way up a tree) to the ground and humanize them. Faith may see herself as a victimized woman, stuck with unremitting childcare, but she is none the less an American, looking down from a height.

Although the narrative appears to digress and meander in a decentred way, idling from anecdote to unrelated anecdote, there is a subtextual logic to its movement, which centres upon notions of distance. Distance undercuts feeling and responsibility in several examples. On the one hand distance allows Mrs Finn to pass judgement. Faith comments that Mrs Finn is 'more in charge of word meanings than I am. She is especially in charge of Good and Bad' (p. 85). Mrs Finn's child, Junior, is actually at some physical distance, imprisoned upstate for theft. The family, however, have managed to disclaim responsibility: 'It was Adam's Fall not Junior that was responsible', distancing from the specific local crime (the desire for a ten-speed Italian racer) to the global conviction of Sin. Lofty definitions of Good and Evil can be a useful means of abdicating from any real moral involvement. In her childhood, Faith herself was celebrated in the press for travelling long distances as 'the third commercial air-flight baby passenger in the entire world' (p. 8o). In her account her mother unsentimentally sent the baby off alone to prove that in some sensible socialist future, 'she wasn't the sort to hang on [...] she wouldn't cry at my wedding' (p. 8o). More mundanely, fathers in the story are both physically and emotionally distant, as in the case

${ }^{11}$ Minako Baba, 'Faith Darwin as Writer-Heroine: A Study of Grace Paley's Short Stories', Studies in American-7ewish Literature, 7.I (I 988), 40-54; Adam Meyer, 'Faith and the "Black Thing": Political Action and Self-Questioning in Grace Paley's Short Fiction', Studies in Short Fiction, 3 I ( I 994), 79-89. 
of Phillip, unsure what age his own son is, now the boy has moved to Chicago, or Ricardo, Faith's absent husband, exploring equatorial regions, and leaving his children to Faith to bring up. Although Faith envies Ricardo his adventurous freedom, his letter to her comprehensively deflates the charms of distance, in favour of the attractions of the local: 'I am not well. I hope I never see another rainforest. I am sick. Are you working? Have you seen Ed Snead? He owes me \$18o' (p. 82). In contrast Faith comically inflates the tiny world of his son, Richard, the 'prince' of the day-care centre for the deprived children of working mothers, 'Lord of the West Side loading zone' whenever it rains on Sundays, 'chief of the dark forest of four ginkgo trees' (p. 87). Unlike his father's, Richard's jungle experiences are emphatically local. A small world suddenly expands here, to the horizon; the 'larger' world shrinks into bathos. Playfully, Faith extols the virtues of the local in a digression describing a plan to make one month of public-school attendance part of the private school curriculum, to demonstrate 'the value of exposing children who had read about the horror at Ilium to ordinary street fights, so they could understand the Iliad better' (p. 9o). The anecdote offers a tonguein-cheek version of the argument that involvement in local issues and political conflicts can inform the understanding of global war.

Importantly, this play with distance is not limited to theme, metaphor, or imagery. In terms of narrative form, manipulations of distance are what make the story politically effective. In the tale (as Jacqueline Taylor has demonstrated in a sophisticated formal analysis) it is often quite difficult to distinguish between Faith's unspoken thoughts, expressed only to the reader, and her direct utterances. When she wonders to herself 'How can you answer that boy?' (p. 84), it is a surprise to the reader when Mrs Junius Finn, 'some distance away' (p. 85) on the other side of the park, actually replies. Faith's empire of the eye is violated by the unpredictable ability of sound, words, to cross long distances. The ironic inflation and deflation of the scene upsets the reader's ability to maintain a safe distance. It is rather as if we had the wrong reading glasses on. The scene jumps suddenly at us. We are not securely outside the story (in our tree), nor are we snugly inviolable, sharing the headspace of a narrator. Other characters, who seemed to be some way away, can suddenly get up close and personal. What seemed like a private monologue for the reader alone, for example, is suddenly dismissed by Richard: 'That's a typical yak yak out of you, Faith' (p. 84). If a reader can be said to have a 'body space' within a story, this story would violate it: perhaps a suggestive metaphor in the context of Vietnam.

As a result, the story insists upon physical closeness rather than aesthetic distance, with a series of incidents in which space expands or contracts according to the dictates of the senses. At times it is as if we were in a whispering gallery, where sound can travel a long way to be audible right beside us; at times it is as if deafness struck at six inches, such is the domination of the visual. Paley had fought to preserve this particular park 
from developers. Importantly, she had also been part of the movement to permit music in the park, seen by city authorities as a threat to civil order: They wouldn't allow any guitars or singing, flutes or oboes, anything. And we finally simply sat down together in the fountain circle with the children, and we just sat and played guitars and recorders and fiddles. [The police] went after us, knocking people around a little. (fust As I Thought, p. I 57)

Paley's group won, though she comments ruefully, 'Now it's so noisy you can hardly stand it' (p. I 58). In the story the subjective limitations of both eye and ear are insisted upon. Mrs Finn is 'deaf to passion' (p. 85); Phillip's 'offended' eyes are described in minute close-up. Richard's teacher is deaf to the attractions of his nonsense verse. The narrator registers one group of upwardly mobile fathers only as the 'whistlers'; her absent husband is portrayed as a ball of spit in her ear. Faith comments that it takes most men two years to appreciate Anna's bad character ('to see how bad she was') but 'it takes the average passer, answerer, or asker about thirty seconds to see how beautiful she is' (p. 97). In contrast, when two music lovers traverse the park, they pay absolutely no attention to the women. Their mental space is entirely filled by a radio playing the Chromatic Fantasy. They are up close, close enough for Anna to hear their comments on the music, but as personally distant as the contemporary user of a personal stereo on a crowded train. Another passer-by, a representational artist, spots Kitty and Antonia and 'squared them off with a filmmaker's viewfinder and said, "Ah, what a picture!", then left' (p. 88). He treats the women as if they were deaf, or some distance away, as if they were merely objects offered to the gaze of the passing male. There are many such males, characterized by Kitty as 'squint-eyed speculators' (p. 88). One such sits down beside Lynn and 'speaks softly to her left ear while she maintains her profile' (p. 86), completely avoiding his eyes. Kitty assumes he is offering her a dramatic role; Faith sees it as obvious that he is a 'weekend queer' suggesting a 'neighborhood threesome' (p. 86). For the reader it is irritating not to know what the unspecified temptation actually was. Successively we crave the omniscience that Paley here denies us, just as we crave the safety of the inviolable narrator, and do not expect her characters to interrupt or criticize her. We are, in readerly terms, in the sky, rather than on the ground. Faith draws a tentative moral:

I don't believe civilisation can do a lot more than educate a person's senses. If it's truth and honor you want to refine, I think the Jews have some insight. Make no images, imitate no God. After all, in His field, the graphic arts, He is preeminent. [Let God] be in charge of Beauty [...] and [...] let man be in charge of Good. (p. 89)

The comment connects the story with a familiar strand of anti-ocular discourse in Western culture, particularly in the contrast between lived, temporally meaningful experience, immediacy of speech (the word) and collective activity, and, on the other hand, dead spatialized images, the 
distancing effect and potential violence of the gaze, and the passivity of individual contemplation. Paley's argument against the dehumanizing effects of the hegemony of the eye draws on a long tradition, from the validation of the Word of God over the graven image, to Foucault's analysis of vision as complicitous in the apparatuses of surveillance, central to the maintenance of repressive power in the modern world. ${ }^{12}$

In descending from her tree, Faith abandons the distant view in favour of the conversation at ground level, the local rather than the global. Paradoxically it is this movement that broadens her moral field of action. Paley has commented in interview on the way in which her involvement in local issues connected to more global action. ${ }^{13}$ The original title of the story was 'Faith: In A Tree'. In the story's second creation, however, the colon was omitted, allowing the pun on faith/belief in a tree. Paley preserved the trees in a small local arena; her character now commits herself to the same action on a global scale. In her accounts of Vietnam Paley dwells, at several reprises, upon the greenness of the landscape, a 'mist of greenness', 'our green Hanoi' (Just As I Thought, pp. 62-64). Oddly, no commentator appears to have drawn the obvious connection between a tree and the Vietnam war. Napalm, as nobody needs to be reminded, is a defoliant. The subtle politics of the story operates subtextually, as opposed to the graphic imagery of the protesters, to translate the local into the global, with the New York park standing as an image of another despoiled area, struggling to preserve its green spaces for its children. When the women, longing for exotic travel, admire Phillip's French, it appears to be merely a digression. "CCambodge ...." Phillip said. He said this softly as though the wars in Indochina might be the next subject for discussion' (p. 95). The reader assumes that they will not be, that Phillip is merely playing with sound. But like a half audible undertone, the sound comes to our attention, culminating in the noise of the anti-war parade. Backing away, circling around, the story closes in on its real topic, catching the reader by surprise. Paley has remarked that she often needs two stories in order to make one: 'It's these two stories working against each other and in connection with each other that make it happen. ${ }^{14}$ By its indirection, the story reverses the proverbial phrase, suggesting that rather than not being able to see the wood for the trees, most of us cannot see the tree for the wood: our views are too global, too distanced, too visual to pick up the message of the word on the ground.

\footnotetext{
12 See Martin Jay, Downcast Eyes: The Denigration of Vision in Twentieth-Century French Thought (Berkeley: University of California Press, I 994).

${ }^{13}$ Wendy Smith, 'PW Interviews Grace Paley', in Conversations With Grace Paley, ed. by Gerhard Bach and Blaine H. Hall (Jackson: University Press of Mississippi, r 997), pp. I 26-3o.

14 'Grace Paley Interviewed by Ruth Perry,' in Women Writers Talking, ed. by Janet Todd (New York: Holmes and Meier, I983), p. 39.
} 